\title{
An exchange could do you good Hosting informal meetings to foster academic librarians' work at nearby institutions
}

A s academic librarians support students' learning, they often neglect their own needs as learners due to time, cost, and resource constraints. However, the need to engage in learning opportunities, especially as instructional needs and technology options evolve, is critical to their success as professionals. Librarians may look for opportunities to learn by connecting with others at conferences, workshops, and webinars. While these formats provide meaningful opportunities for academic librarians to meet and learn from each other, they are often costly for both institutions and individuals, disconnected from work environments, and do not consider the contextual factors that influence librarians' day-to-day jobs. Moreover, the COVID-19 pandemic has restricted both travel possibilities, and travel funding — in many cases, for the foreseeable future.

There is room, then, to explore an additional approach to professional learning: informal, exchange-style partnerships between two academic libraries at similar institutions that might happen in person or online. As librarians at two academic libraries in close proximity and with similar characteristics, we initiated an in-person librarian exchange program in 2017. Because we found this initiative to be useful, our experiences_-both learning and logistical—can help others consider whether such an option is feasible at their own institutions, and how a similar undertaking might happen remotely.

\section{Important factors in planning partnerships}

Successful library partnerships have long ex- isted between academic libraries and nearby public or school libraries. In the most proactive instances, these relationships may develop around programming or educational initiatives that seek to positively and holistically impact student learning. ${ }^{1}$ However, other academic libraries may seek out or establish these partnerships for cost-sharing or to address resource gaps. ${ }^{2}$ While these kinds of relationships do not seek to meet academic librarians' ongoing learning needs, they do highlight the need for clear communication and regular check-ins to ensure the ongoing success of such partnerships. In terms of institutional collaboration related to professional learning, academic librarians have partnered with campus development centers to advance the scholarship of teaching and learning at their institutions. ${ }^{3}$ These intra-institutional relationships can have benefits on both sides: Academic librarians can develop their instructional capacities, and the broader campus community can integrate information literacy into learning environments.

Similarly, academic library mentorship is interpersonally grounded and involves

Suzanne Gray is professor, email: suzanne.gray@emich. edu, Bill Marino is associate professor, online learning librarian, email:wmarino1@emich.edu, Amanda Nichols Hess is associate professor, coordinator of instruction and research help, email: nichols@oakland.edu, Beth Wallis is professor, coordinator of assessment, email: wallis@oakland.edu, at Oakland University

(c) 2020 Suzanne Gray, Bill Marino, Amanda Nichols Hess, and Beth Wallis 
relationship-building. In these programs, regularly scheduled meetings and structured discussion topics can help to facilitate connections and professional growth. ${ }^{4}$ And larger academic libraries may develop internal exchange programs, where librarians with similar responsibilities can share best practices. At smaller institutions, matching up with someone who has a similar portfolio that mimics this approach is particularly useful..$^{5}$ These relevant professional learning-centric concepts can relate to partnerships between academic libraries, and help us understand how informal learning relationships can develop.

\section{About our institutions}

Eastern Michigan University (EMU) is located in Ypsilanti, Michigan, just under 40 miles west of Detroit and less than 10 miles southeast of Ann Arbor. It is a CarnegieClassification R2 institution, and more than 18,800 students were enrolled at EMU as of fall 2018. ${ }^{6}$ Oakland University (OU) is located in Rochester, Michigan, just under 30 miles north of Detroit and approximately 50 miles northeast of Ann Arbor. OU is a Carnegie-Classification R2 institution, and more than 19,300 students were enrolled at OU as of fall 2018.7 Both institutions attract nontraditional students, as well as commuter students and transfer students from community colleges and other four-year institutions.

EMU and OU's institutional profiles align in many ways, and these commonalities extend to their academic libraries. At both universities, librarians hold faculty status, are members of active faculty unions, and work toward tenure with flexible schedules: eight-month contracts with the possibility of summer extensions for EMU librarians, and eight-month contracts for OU's librarians. This particular factor was unique to these academic libraries, especially when compared to other public universities in the same geographic area. And, the number of liaison librarians was comparable at both institutions. The EMU and OU academic librarians had encountered similar needs, challenges, and opportunities in working with instructors and learners across their programs.

\section{The EMU-OU exchanges}

The seed of our library exchanges was planted in a conversation that Amanda Nichols Hess from OU Libraries had with a former colleague about librarians' anxiety around teaching observations. That librarian's academic library partnered with a nearby institution to do an observation exchange, where librarians from each of the participating institutions observed someone at the other academic library so as to reduce the sense of being evaluated. This approach piqued Hess's interest: It seemed to offer constructive, meaningful ways to learn from neighboring librarians.

Hess had worked with Bill Marino, an EMU librarian, on a statewide committee and in an ALA Immersion program. She remembered that their institutions had some commonalities. Hess thought that some sort of informal learning partnership might benefit librarians at both universities, so she approached Beth Wallis, OU Libraries' coordinator of instruction, about investigating an informal, instructionalcentric exchange with EMU librarians. With Wallis's go-ahead, Hess reached out to Marino in fall 2017 with the idea of an instructional exchange. He shared the idea with his library colleagues, and a number expressed interest in such a connection. Marino worked with Suzanne Gray, EMU's library instruction coordinator, to gather a group interested in visiting OU Libraries in fall 2017.

As they planned the first exchange meeting, Marino shared with Hess that the EMU librarians felt it was important to have a structure or topic for any session. Each institution agreed that a kick-off meeting on the Framework for Information Literacy for Higher Education would be a useful starting point. This kind of planning helped to guide subsequent meetings and, once the initial logistics had been planned, Hess and Wallis acted as consistent points of contact throughout.

In December 2017, OU Libraries hosted the institutions' first instructional exchange. This half-day meeting focused on the Framework, and several OU librarians shared how they tackled these concepts in their teaching. OU 
Libraries' administration provided lunch, and the group went on brief tours of OU Libraries' MakerSpace and Archives and Special Collections. There was some initial awkwardness in getting started, but there was a good deal of discussion around similar roles, issues, and considerations by the end of this meeting. After our session, each group independently agreed that it would be worthwhile to have another session in spring 2018.

In March 2018, EMU librarians hosted another instructional exchange between the groups. This time, the topic focused on instruction and assessment. Librarians from both institutions shared ideas about integrating assessment into their teaching, including initiatives that did-and didn't!-go as planned, as well as lessons learned from such work. This time, EMU's library administration provided lunch for the group, and the EMU librarians led the visitors from OU on a tour of their Automated Retrieval Collection storage and Academic Projects Center.

At this point, both groups revisited what a meaningful librarian exchange relationship would look like. They had explored instruction-related issues in formal ways; what additional approaches would be useful going forward? OU's librarians identified that continued informal conversations-focused on areas or issues of interest-could help them to learn and grow professionally. OU Libraries hosted another half-day exchange in the spring 2019, where, again, the administration provided lunch. While the session started with a general presentation-this time about streaming video and demand-driven acquisitions-the group broke into several discussion groups focusing on space for collections and in-library partnerships, tools to facilitate work, using special collections and instruction, and OER initiatives. These focused discussions then led into the lunch session, which wrapped up the spring meeting.

While the exchange participants undoubtedly had their own takeaways from these meetings, there are several broad conclusions we experienced and that others may find relevant. Most importantly, these ses- sions helped us to get to know the people we encounter at statewide conferences and at other instruction-focused events. Librarians' experiences in these three meetings highlighted that such sessions can offer meaningful connection opportunities around common issues, liaison responsibilities, areas of interest, or other factors that are of mutual interest. Also, meaningful projects can develop from these simple interactions, both across institutions and within libraries. For example, the health sciences librarians at both institutions have presented at conferences together and have an article in development about their liaison work, and two of OU's librarians found unexpected common ground around an assessment-related project as a result of the March 2018 meeting. ${ }^{8}$ These exchanges provided opportunities to connect with librarians both outside of and within our work environments. And, most practically, these meetings were low-cost. In our cases, the only expenses were food and transportation related. While both libraries' administrations funded lunch, these meetings could have been even less expensive without refreshments. Therefore, cost need not be an obstacle in establishing such relationships.

\section{Key takeaways}

For academic librarians interested in exploring such an initiative at their own institutions, there are several questions they should consider:

- Around what areas can meaningful relationships be created? Identify the unique factors of your academic library environment that may apply to another (relatively close) neighboring institution. In the case of EMU and OU, the librarians' status and schedule, our institutions' student demographics, and our universities' characteristics helped make our exchanges meaningful. For other academic librarians, partnerships might center around location, common strategic goals, or organizational structure (e.g., departments within a large library system that have similar counterparts at another institution). Identifying these factors, and 
finding partnering libraries with these components, is an important foundational step.

- Where are potential areas of growth for your academic librarians? Carefully consider what professional development would be most meaningful for your group of librarians. For example, would instructional observations, which first sparked this idea, be useful? Do librarians need to learn about different instruction, collection, or research help strategies? Or do librarians simply want to connect professionally with peers outside of their institution? Establishing the learning or development goals can help to identify what kinds of partnerships can be most useful and set clear goals for all.

- What are the constraints you need to consider? Relationships form-and can be restricted-around distance, schedule/timing, and cost. While library exchanges can offer meaningful opportunities for partnership and learning, they will fall flat if limitations are not mitigated or at least acknowledged in advance. In weighing these issues at the outset, librarians may be more able to plan for them and work around them. And in some cases, a virtual option may be the most relevant, if technology allows.

Our libraries' informal exchanges offered opportunities for professional development while still considering the unique constraints of our institutions. Although changing work responsibilities meant we had to pause them for the 2019-20 academic year and COVID-19 has staunched any immediate plans to reconvene at an institution, we do not feel this partnership has reached the end of its lifespan. We look forward to picking up these exchanges again in the near future with an eye toward the ongoing issues and opportunities in librarianship, and we are considering what may work for us in an online setting. Depending on an academic library's contexts and needs, such a partnership may support librarians as they work with students, faculty, and staff in relevant, novel ways.

\section{Notes}

1. Katelyn Angell and Eamon Tewell,
"Collaborating for Academic Success: A TriInstitutional Information Literacy Program for High School Students," Public Services Quarterly 9, no. 1 (2013): 1-19.

2. Kathleen Halverson and Jean Plotas, "Creating and Capitalizing on the Town/ Gown Relationship: An Academic Library and a Public Library form a Community Partnership," The Journal of Academic Librarianship 32, no. 6 (2006): 624-29.

3. Melissa Mallon et al., (eds.), The Grounded Instruction Librarian: Participating in the Scholarship of Teaching and Learning (Chicago: Association of College and Research Libraries, 2019).

4. Mandi Godsett and Andrew Walsh, "Building a Strong Foundation: Mentoring Programs for Novice Tenure-Track Librarians in Academic Libraries," College E Research Libraries 76, no. 5 (2015): 914-33.

5. See, for example: University of Michigan Libraries, "Instructor College Current Projects," https://www.lib.umich.edu /instructor-college/current-projects (accessed December 17, 2019); Laurie Alexander, Suzanne Gray, and Patricia Yocum, "Teaching the Teachers: Creating an Intensive Staff Development Program for Library Instructors," LOEX News 28, nos.2-3 (2001): $4+$.

6. Eastern Michigan University, "Fast Facts," https://www.emich.edu/ facts/index.php (accessed December 10, 2019).

7. Oakland University Office of Institutional Research and Assessment, "Enrollment," https://www.oakland.edu/oira /student-information/enrollment/ (accessed December 10, 2019).

8. Julia Rodriguez and Elizabeth Bucciarelli, "The Mail Never Stops. It Just Keeps Coming and Coming and Coming: Providing Research Support and Instruction to High-enrollment Programs," Conference Presentation given at MI-ALA Annual Conference, East Lansing, Michigan, May 2018, https://www.miala.org /docs/The_mail_never_stops.pdf. $\boldsymbol{\neq}$ 